\title{
Anti-apoptotic N-cadherin signaling and its prognostic implication in human hepatocellular carcinomas
}

\author{
GEUM-YOUN GWAK ${ }^{1}$, JUNG-HWAN YOON ${ }^{1}$, SU JONG YU ${ }^{1}$, SU CHEOL PARK ${ }^{1}$, \\ JA JUNE JANG ${ }^{2}$, KYOUNG BUN LEE ${ }^{2}$, SUNG-HEE LEE ${ }^{1}$, SOO-MI LEE ${ }^{1}$, \\ CHAN SOO SHIN ${ }^{1}$, KYUNG-SUK SUH ${ }^{3}$ and HYO-SUK LEE ${ }^{1}$ \\ Departments of ${ }^{1}$ Internal Medicine, ${ }^{2}$ Pathology and ${ }^{3}$ Surgery, \\ Seoul National University College of Medicine, Seoul, Republic of Korea
}

Received December 6, 2005; Accepted February 10, 2006

\begin{abstract}
N-cadherin signaling has recently been implicated in the progression of certain epithelial tumors by promoting invasion and dissemination of cancer cells. N-cadherin has also been reported to exert an anti-apoptotic effect. In this study, we attempted to evaluate the participation of this adhesion molecule in the progression of human hepatocellular carcinomas (HCCs) by analyzing its anti-apoptotic signaling as well as its prognostic implication in HCC patients. $\mathrm{N}$-cadherin was found to be expressed in human HCCs. We established a stable human HCC cell line expressing a truncated $\mathrm{N}$-cadherin, $\mathrm{NCad} \Delta \mathrm{C}$, with a dominant-negative action. $\mathrm{NCad} \Delta \mathrm{C}$-expressing cells were more susceptible to bile acid-induced apoptosis than control cells. N-cadherin was found to complex with procaspase- 8 , and this association was diminished in $\mathrm{NCad} \Delta \mathrm{C}$-expressing cells, leading to enhanced procaspase- 8 recruitment to death-inducing signaling complex following bile acid treatment. A clinicopathological analysis in patients who had undergone surgical resection for $\mathrm{HCC}$ revealed that tumoral N-cadherin up-regulation was significantly related to poor recurrencefree and overall survival. Our findings implicate $\mathrm{N}$-cadherin signaling as contributing to HCC progression by exerting anti-apoptotic effects. Thus, we suggest that the selective interruption of this signaling may have therapeutic potential.
\end{abstract}

Correspondence to: Dr Jung-Hwan Yoon, Seoul National University College of Medicine, Yungun-dong 28, Chongno-gu, Seoul 110-744, Republic of Korea

E-mail: yoonjh@snu.ac.kr

Abbreviations: HCC, hepatocellular carcinoma; DC, deoxycholate; DAPI, 4',6-diamidino-2-phenylindole dihydrochloride; FADD, Fas associated death domain; RFS, recurrence-free survival; OS, overall survival; DISC, death-inducing signaling complex

Key words: N-cadherin, hepatocellular carcinoma, apoptosis, caspase-8, recurrence, survival

\section{Introduction}

Hepatocellular carcinoma (HCC) development is a major cause of mortality in chronic liver disease patients. Massforming or even locally advanced HCCs can be efficiently eradicated by surgical resection or locoregional therapies. However, the long-term prognosis for these patients remains unsatisfactory due to high rates of tumor recurrence, and there is therefore a need to understand the clinicopathological features of HCCs in the broadest sense. In recent years, the development of cellular and molecular biological techniques has allowed extensive studies to be conducted on many factors potentially related to cancer cell invasion, metastasis, recurrence and patient survival. These include alterations in DNA ploidy, cellular proliferation markers, tumor suppressor and promoter genes, cell cycle regulators, proteinases that degrade the extracellular matrix, angiogenic factors, and adhesion molecules (1).

Alterations in the cadherin/catenin intercellular adhesion system are known to be involved in the invasiveness and metastatic behavior of certain tumors. E-cadherin is representative of the classic cadherins, and its downregulation has frequently been related to invasiveness, metastasis, and a poor prognosis in a variety of human cancers, including $\operatorname{HCC}(2,3)$. On the other hand, $\beta$-catenin, which was originally identified as a submembrane component in the cadherin-mediated cell-cell adhesion system, functions as a downstream transcriptional activator of the Wnt signaling pathway and forms a complex with the DNA-binding proteins, T-cell factor and lymphoidenhancer factor 1 (4). Moreover, unlike E-cadherin, B-catenin expression correlates positively with HCC grade and is highest in poorly differentiated HCCs (2).

In addition to E-cadherin/ß-catenin deregulation, $\mathrm{N}$-cadherin signaling has also been shown to participate in the progression of certain epithelial tumors $(5,6)$. N-cadherin expression is usually observed in neural tissue and fibroblasts (7-9), where it is believed to mediate a less stable and more dynamic form of cell-cell adhesion (10). Therefore, aberrant N-cadherin expression in tumors may lead to the acquisition of a migrating and invasive phenotype by cancer cells. In addition to promoting cancer cell invasion, it has also been suggested that $\mathrm{N}$-cadherin signaling may contribute to the progression 
of tumors by exerting an anti-apoptotic effect (11). However, the participation of $\mathrm{N}$-cadherin signaling in the progression of human HCC has not yet been clarified.

In this study, we hypothesized that anti-apoptotic $\mathrm{N}$-cadherin signaling is involved in HCC progression. To test this hypothesis, we formulated the following questions: i) Is $\mathrm{N}$-cadherin expressed in human HCCs? ii) Does N-cadherin signaling affect cellular apoptosis? If so, iii) what is the antiapoptotic mechanism mediated by N-cadherin? And finally, iv) does $\mathrm{N}$-cadherin signaling have prognostic implications in HCC patients? Collectively, the results of the current study demonstrate that $\mathrm{N}$-cadherin signaling is involved in HCC cell apoptosis, and tumoral $\mathrm{N}$-cadherin up-regulation is associated with tumor recurrence and a poor outcome in HCC patients following surgical resection. Therefore, our findings implicate $\mathrm{N}$-cadherin signaling during HCC progression, and suggest that interrupting this signaling may have therapeutic potential.

\section{Materials and methods}

Cell culture and reagents. Huh-BAT cells (Huh-7 cells, a welldifferentiated human HCC cell line, stably transfected with a bile acid transporter) were grown in DMEM supplemented with $10 \%$ fetal bovine serum, penicillin 100,000 U/1, and streptomycin $100 \mathrm{mg} / \mathrm{l}$ (12). Two other human HCC cell lines with poorly differentiated phenotypes, SNU-475 (13) and SNU-761 (14), were grown in RPMI-1640 supplemented with $10 \%$ fetal bovine serum, 100,000 U/1 penicillin and $100 \mathrm{mg} / \mathrm{l}$ streptomycin. In all experiments performed in this study, cells were serum-starved overnight to avoid the effects of serum-induced signaling. Deoxycholate (DC) was obtained from Sigma Chemicals Co. (St. Louis, MO).

Plasmids. The NCad $\Delta \mathrm{C}$ construct, cloned in the pSP72 (pSP72NCad $\Delta \mathrm{C}$ ) vector, was obtained from Dr Jeffery Gordon (Washington University, St. Louis, MO) with the permission of Dr Chris Kintner (Salk Institute, San Diego, CA). This construct, derived from an in-frame deletion of most of the extracellular domain of Xenopus $\mathrm{N}$-cadherin, has been shown to function as a dominant negative cadherin $(15,16)$. A hemagglutinin epitope was incorporated at the C-terminal of $\mathrm{NCad} \Delta \mathrm{C}$ by PCR, then ligated into the $B g l \mathrm{II} /$ EcoRI site of pMSCV-IRES-GFP retroviral vector (kind gift from Neil A. Clipstone, Northwestern University, Chicago, IL) upstream of IRES, giving pMSCV-NCad $\triangle \mathrm{C}$-IRES-GFP.

Retrovirus generation and transduction. For the transient generation of VSV-G pseudo-typed retrovirus, 293T cells were transfected with pMD-gag-pol, pMD-VSVG [both obtained from Dr Richard C. Mulligan (Harvard Medical School, Boston, MA)] and the retroviral vector, $\mathrm{pMSCV}-\mathrm{NCad} \Delta \mathrm{C}$ IRES-GFP or pMSCV-IRES-GFP, using LipofectAmine Plus reagents (Invitrogen, Carlsbad, CA). Huh-BAT cells were transduced with virus-containing supernatants in the presence of $5 \mu \mathrm{g} / \mathrm{ml}$ polybrene for $5 \mathrm{~h}$. Cells were collected $48-72 \mathrm{~h}$ later, and GFP-positive fractions were FACS-sorted using a BD FACS Vantage Cell Sorter (Franklin Lakes, NJ).

Apoptosis. Apoptosis was assessed by examining the nuclear changes associated with apoptosis (i.e. chromatin condensation
Table I. The baseline characteristics of HCC patients.

\begin{tabular}{|c|c|}
\hline Variable & $\mathrm{n}(\%)$ \\
\hline \multicolumn{2}{|l|}{ Age (years) } \\
\hline$<50$ & $31(37)$ \\
\hline$\geq 50$ & $53(63)$ \\
\hline \multicolumn{2}{|l|}{ Sex } \\
\hline Male & $74(88)$ \\
\hline Female & $10(12)$ \\
\hline \multicolumn{2}{|l|}{ Child class } \\
\hline A & $82(98)$ \\
\hline B & $2(2)$ \\
\hline \multicolumn{2}{|l|}{ Viral hepatitis } \\
\hline B & $60(71)$ \\
\hline $\mathrm{C}$ & $11(13)$ \\
\hline $\mathrm{B}+\mathrm{C}$ & $4(5)$ \\
\hline NBNC & $9(11)$ \\
\hline \multicolumn{2}{|l|}{ UICC T } \\
\hline $\mathrm{T} 1$ & $59(70)$ \\
\hline $\mathrm{T} 2 / 3$ & $25(30)$ \\
\hline \multicolumn{2}{|l|}{ Multiplicity } \\
\hline Yes & $6(7)$ \\
\hline No & $78(93)$ \\
\hline \multicolumn{2}{|l|}{ Vascular invasion } \\
\hline Yes & $23(27)$ \\
\hline No & $61(73)$ \\
\hline \multicolumn{2}{|l|}{ Grade } \\
\hline Low (I-II) & $47(56)$ \\
\hline High (III-IV) & $37(44)$ \\
\hline
\end{tabular}

and nuclear fragmentation) using the nuclear binding dye, 4',6-diamidino-2-phenylindole dihydrochloride (DAPI), and fluorescence microscopy (Zeiss, Germany).

Immunoblotting. Cells were lysed for $20 \mathrm{~min}$ on ice with lysis buffer (50 mM Tris-HCl, pH 7.4; $1 \%$ Nonidet P-40; $0.25 \%$ sodium deoxycholate; $150 \mathrm{mM} \mathrm{NaCl} ; 1 \mathrm{mM}$ EDTA; $1 \mathrm{mM}$ PMSF; $1 \mu \mathrm{g} / \mathrm{ml}$ aprotinin, leupetin, pepstatin; $1 \mathrm{mM} \mathrm{Na} \mathrm{VO}_{4}$; and $1 \mathrm{mM} \mathrm{NaF}$ ) and centrifuged at $14,000 \mathrm{x}$ g for $10 \mathrm{~min}$ at $4{ }^{\circ} \mathrm{C}$. Samples were resolved with $10 \%$ or $12 \%$ SDS-PAGE, transferred to PVDF membranes, and blotted using appropriate primary antibodies and peroxidase-conjugated secondary antibodies (Biosource International, Camarillo, CA). Bound antibodies were visualized using chemiluminescent substrate (ECL; Amersham, Arlington Heights, IL) and exposed to Kodak X-OMAT film. The primary antibodies used were mouse anti-N-cadherin from BD Transduction Laboratories (San Jose, CA); rabbit anti-caspase-10 from Cell Signaling Technology, Inc. (Beverly, MA); rabbit anti-caspase-8, rabbit anti-caspase-3 and mouse anti-Fas-associated death domain (FADD) from Pharmingen (San Diego, CA); goat anti-TRAIL- 
A

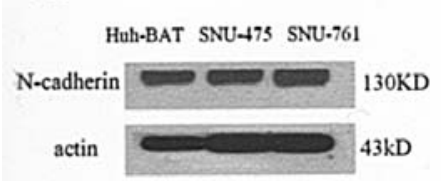

B

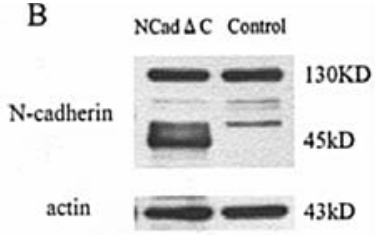

Figure 1. Establishment of an HCC cell line expressing dominant-negative N-cadherin. (A) Cell lysates of human HCC cell lines, i.e. Huh-BAT, SNU475 and SNU-761 cells, were immunoblotted with anti-N-cadherin and antiactin antibodies. (B) Huh-BAT cells were infected with either a retroviral vector pMSCV-NCad $\Delta$ C-IRES-GFP encoding NCad $\Delta \mathrm{C}$ (a truncated Ncadherin with a dominant-negative action) or a control vector. $\mathrm{NCad} \Delta \mathrm{C}$ and control cell lysates were immunoblotted with anti-N-cadherin and anti-actin antibodies.

R2/DR5 and rat anti-cFLIP from Alexis (San Diego, CA); goat anti-bid from R\&D Systems (Minneapolis, MN); and rabbit anti-Bax, mouse anti-Bcl-2 and goat anti-actin from Santa Cruz Biotechnology Inc. (Santa Cruz, CA).

Immunoprecipitation. Cells were lysed in lysis buffer as described above, and the lysates were incubated with either mouse anti-caspase-8 (Upstate USA, Inc., Chicago, IL) or mouse anti-FADD antibody (Pharmingen) overnight at $4^{\circ} \mathrm{C}$. Immune complexes were precipitated with $50 \mu$ l of protein A/G Plus agarose beads (Santa Cruz Biotechnology Inc.) for $2 \mathrm{~h}$ at $4^{\circ} \mathrm{C}$ and then washed five times with lysis buffer. Polypeptides were eluted from the beads by boiling for $5 \mathrm{~min}$ in 2X Laemmli sample buffer, and the immunoprecipitates were then immunoblotted with anti-N-cadherin, anti-caspase-8, anti-TRAIL-R2/DR5 or anti-FADD antibody.

Patients. Eighty-four patients (74 men and 10 women; mean age, $53 \pm 10$ years) who had undergone surgical resection at Seoul National University Hospital between June 1994 and December 1998 were retrospectively included in this study. Baseline characteristics of the study population are detailed in Table I. During follow-up periods of 1-108 months (median 48 months), HCC recurred in $58(69 \%)$ patients [median recurrence-free survival (RFS) time following resection, 22 months; $95 \%$ confidence interval (CI), 13-31 months], and 52 $(62 \%)$ patients died [median overall survival (OS) time following resection, 48 months; $95 \%$ CI, 39-57 months]. Causes of death were HCC progression in 25 cases, hepatic failure in 13 cases, gastrointestinal bleeding in 2 cases, spontaneous bacterial peritonitis in 1 case, hepatorenal syndrome in 1 case, other causes in 7 cases, and unknown causes in 3 cases. The study protocol was approved by the Seoul National University Hospital Institutional Review Board.

Tissue array and immunohistochemistry. HCC specimens from each patient were processed into $10 \%$ neutral formalinfixed, paraffin-embedded blocks. All tumors were histologically diagnosed, graded according to Edmonson's scale, and grouped as low (I-II) or high grade (III-IV). Tumors were also stratified according to multiplicity and the presence or absence of microscopic vascular invasion. These pathological findings are summarized in Table I.

For immunohistochemical staining, all specimens were evaluated using a tissue-array method. Core tissue biopsies

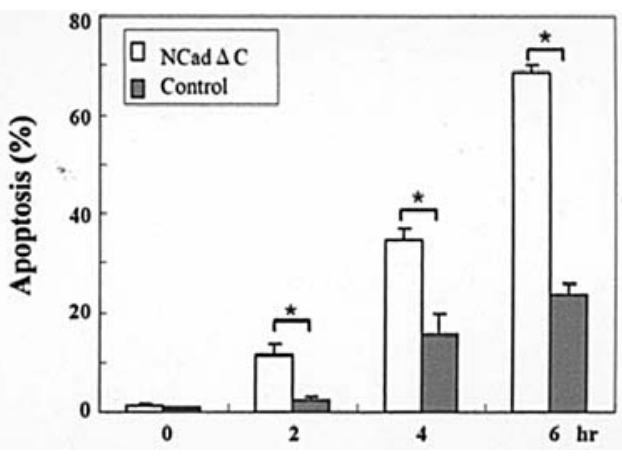

Figure 2. N-cadherin-dependent modulation of $\mathrm{HCC}$ cell apoptosis. $\mathrm{NCad} \Delta \mathrm{C}$ and control cells were incubated with deoxycholate $(200 \mu \mathrm{M})$ for the indicated times. Apoptosis was quantitated by DAPI staining and fluorescence microscopy. Data are expressed as the means \pm SD of three individual experiments. ${ }^{*} \mathrm{p}<0.050$, vs. control.

( $2 \mathrm{~mm}$ in diameter) were taken from individual paraffinembedded tissues (donor blocks) and arranged in a new recipient paraffin block (tissue array block) using a trephine apparatus (Superbiochips Laboratories, Seoul, Korea). Immunohistochemical staining was performed using E-cadherin, $\beta$-catenin (BD Transduction Laboratories) and N-cadherin (Zymed Laboratories Inc., San Francisco, CA) antibodies, and using a streptavidin peroxidase-based procedure after microwave antigen retrieval. The intensity of immunoreactivity in each case was scored as none to weak, moderate, or strong, and the extent of immunoreactivity was scored as less than one-third, one-third to two-thirds, or more than two-thirds. The histological examination was carried out by a pathologist (J.J. Jang) who was blinded to any clinical information.

Data analysis. All in vitro experimental data represent at least three independent experiments using cells from a minimum of three separate isolations and are expressed as means \pm SD. Differences between groups were compared using the two-tailed Student's t-test. RFS and OS were estimated using the Kaplan-Meier method for the clinicopathological variables of age, sex, viral hepatitis, child classification, multiplicity, vascular invasion, stage and grade, or the biological markers of E-cadherin, B-catenin, and $\mathrm{N}$-cadherin, and were compared using the log-rank test. To identify independent prognostic factors affecting RFS and OS, multivariate analysis was performed using the Cox proportional hazard model for variables with $\mathrm{p}$-values $<0.100$ by univariate analysis. More generous p-value criteria were used to include characteristics with a marginal association. All statistical analyses were performed using SPSS version 12.0 (SPSS, Chicago, IL). p-values $<0.050$ were considered statistically significant.

\section{Results}

Establishment of a human HCC cell line expressing dominantnegative $\mathrm{N}$-cadherin. Initially, we examined $\mathrm{N}$-cadherin expression in human HCC cell lines. As shown in Fig. 1A, $\mathrm{N}$-cadherin was expressed in all three human HCC cell lines examined, including one well-differentiated and two poorly 


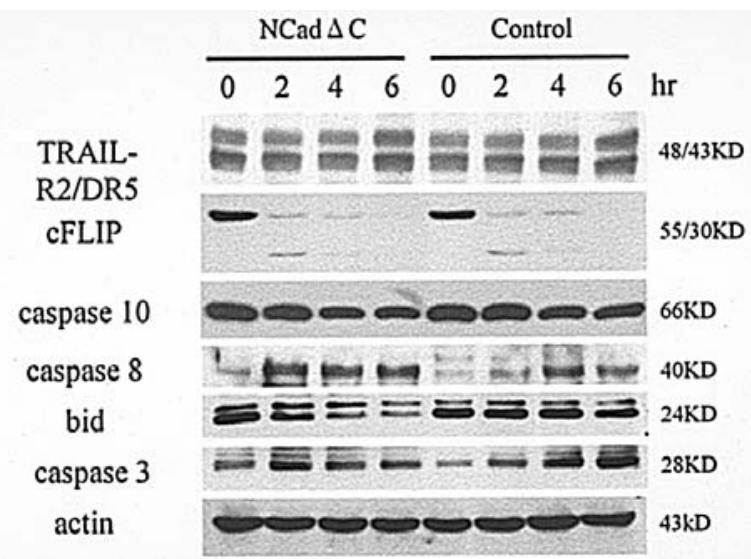

Figure 3. Potentiation of apoptosis in HCC cells expressing dominantnegative $\mathrm{N}$-cadherin. $\mathrm{NCad} \Delta \mathrm{C}$ and control cells were incubated with deoxycholate $(200 \mu \mathrm{M})$ for the indicated times. Cell lysates were immunoblotted with each indicated antibody.

differentiated. Among these, the Huh-BAT cell line was selected for the establishment of dominant-negative $\mathrm{N}$-cadherin-expressing cells, since these cells are susceptible to bile acid-induced apoptosis (12). $\mathrm{NCad} \Delta \mathrm{C}$, a truncated $\mathrm{N}$-cadherin mutant lacking extracellular domains, was found to prevent the lateral clustering and dimerization of endogenous $\mathrm{N}$-cadherins, and thus inhibit the formation of the adhesion complex $(17,18)$. Thus, we established an $\mathrm{NCad} \Delta \mathrm{C}$-expressing cell line, i.e. Huh-BAT cells expressing a truncated $(45 \mathrm{kDa})$ $\mathrm{N}$-cadherin, following transduction of retroviruses containing the $\mathrm{Ncad} \Delta \mathrm{C}$ construct (Fig. 1B).

Does the inhibition of $\mathrm{N}$-cadherin signaling affect $\mathrm{HCC}$ cell survival? We next evaluated the effect of $\mathrm{N}$-cadherin signaling on HCC cell survival by comparing apoptosis in $\mathrm{Ncad} \Delta \mathrm{C}$ and control cells. For this purpose, cellular apoptosis was induced by treating these cells with bile acid. As shown in Fig. 2, NCad $\Delta \mathrm{C}$ cells were more susceptible to bile acidinduced apoptosis than control cells, suggesting the antiapoptotic function of $\mathrm{N}$-cadherin signaling .

We further explored the nature of $\mathrm{N}$-cadherin antiapoptotic signaling by comparing bile acid-induced apoptotic signaling cascades in $\mathrm{NCad} \Delta \mathrm{C}$ and control cells. Bile acidinduced TRAIL-R2/DR5, c-FLIP and caspase-10 modulations
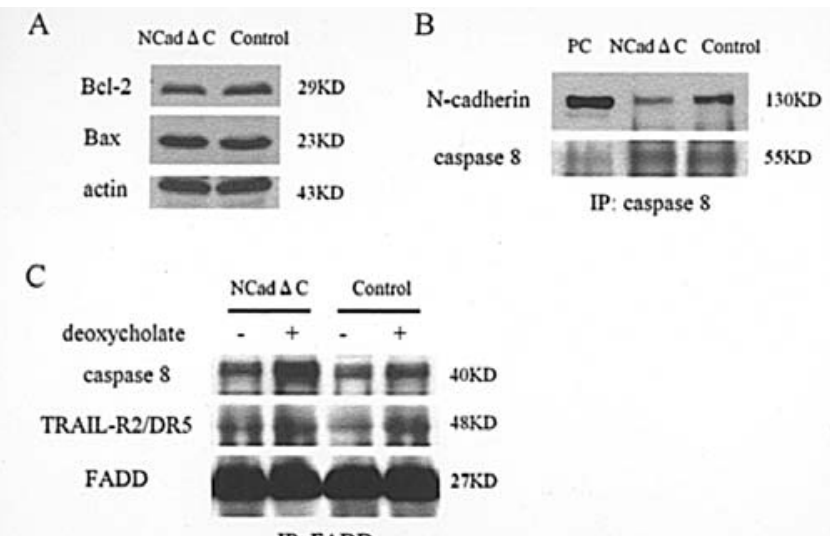

IP: FADD

Figure 4. N-cadherin-dependent anti-apoptotic signaling. (A) Cell lysates of $\mathrm{NCad} \Delta \mathrm{C}$ and control cells were immunoblotted with anti-Bcl-2, anti-Bax, and anti-actin antibodies. (B) Caspase- 8 was immunoprecipitated from both cell lysates. The immunoprecipitates were immunoblotted using anti-Ncadherin and anti-caspase-8 antibodies. PC, positive control. (C) NCad $\Delta \mathrm{C}$ and control cells were treated with deoxycholate $(200 \mu \mathrm{M})$ or media for $2 \mathrm{~h}$. FADD was immunoprecipitated from cell lysates, and immunoblotted using each indicated antibody.

were similar in both cell lines, whereas caspase- 8 and its downstream signal activation were significantly enhanced in $\mathrm{NCad} \Delta \mathrm{C}$ cells (Fig. 3). The expression levels of Bcl-2 and Bax were similar in both cell lines (Fig. 4A). However, N-cadherin formed a complex with procaspase-8, and this association was diminished in $\mathrm{NCad} \Delta \mathrm{C}$ cells versus the control (Fig. 4B). Accordingly, bile acid-induced procaspase- 8 recruitment to FADD was significantly enhanced in $\mathrm{NCad} \Delta \mathrm{C}$ cells versus the control (Fig. 4C). Therefore, these results collectively demonstrate that $\mathrm{N}$-cadherin has an anti-apoptotic function in HCC cells, which involves complexing with procaspase- 8 , and reduced procaspase-8 recruitment to death-inducing signaling complex (DISC).

Does $N$-cadherin expression in HCC predict prognosis? We finally investigated whether tumoral $\mathrm{N}$-cadherin expression is associated with $\mathrm{HCC}$ recurrence or postoperative survival in HCC patients. Of 84 HCC specimens examined, 31, 33 and 20 showed none to weak, moderate, or strong $\mathrm{N}$-cadherin immunoreactivity at cell membranes, respectively. Fig. 5 shows representative cases.

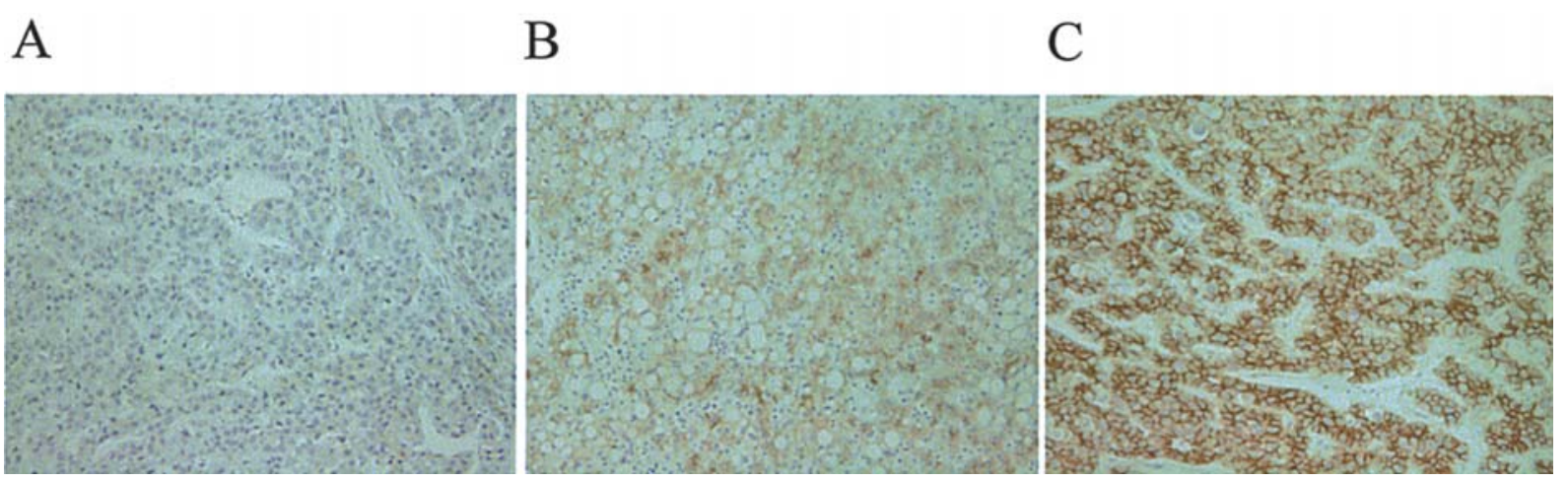

Figure 5. N-cadherin immunoreactivity in human HCC tissue. Representative immunohistochemical staining of (A) none to weak, (B) moderate, and (C) strong $\mathrm{N}$-cadherin immunoreactivity in human HCC tissue. Original magnification, x 200 
Table II. Univariate analysis of clinicopathological and biological variables with respect to RFS and OS.

\begin{tabular}{ccccc}
\hline & RFS & OS & \\
n & $\left(\mathrm{mo}^{\mathrm{a}}\right)$ & $\mathrm{p}$-value & $\left(\mathrm{mo}^{\mathrm{a}}\right)$ & $\mathrm{p}$-value
\end{tabular}

\begin{tabular}{llllll}
\hline Age (years) & & & & & \\
$<50$ & 31 & 29 & 0.475 & 43 & 0.818 \\
$\geq 50$ & 53 & 22 & & 50 &
\end{tabular}

\section{Sex}

$\begin{array}{lllll}\text { Male } & 74 & 21 & 0.570 & 48 \\ \text { Female } & 10 & 33 & & 53\end{array}$

Child class

$\begin{array}{lrrrr}\text { A } & 82 & 23 & 0.163 & 50 \\ \text { B } & 2 & 9 & & 19\end{array}$

Viral hepatitis

$\begin{array}{lrrrrr}\text { B } & 60 & 26 & 0.680 & 48 & 0.753 \\ \text { C } & 11 & 22 & & 104 & \\ \text { B+C } & 4 & 14 & & 39 & \\ \text { NBNC } & 9 & 20 & & 53 & \end{array}$

UICC T

$\mathrm{T} 1$

$59 \quad 33$

0.031

0.039

$\mathrm{T} 2 / 3$

Multiplicity

Yes

No

$\begin{array}{rr}6 & 9 \\ 78 & 26\end{array}$

E-cadherin

intensity

$\begin{array}{llllll}\text { None to weak } & 32 & 38 & 0.139 & 50 & 0.710 \\ \text { Moderate } & 31 & 20 & & 44 & \\ \text { Strong } & 21 & 18 & & 56 & \end{array}$

E-cadherin

extent

$\begin{array}{lll}<1 / 3 & 32 & 18 \\ \geq 1 / 3,<2 / 3 & 21 & 17 \\ \geq 2 / 3 & 31 & 33\end{array}$

$0.237 \quad 46$
46
104

$\mathrm{N}$-cadherin

intensity

$\begin{array}{llllrl}\text { None to weak } & 31 & 41 & 0.014 & 104 & 0.090 \\ \text { Moderate } & 33 & 20 & & 50 & \\ \text { Strong } & 20 & 12 & & 39 & \end{array}$

$\mathrm{N}$-cadherin

extent

$\begin{array}{lrrrrr}<1 / 3 & 35 & 27 & 0.214 & 48 & 0.864 \\ \geq 1 / 3,<2 / 3 & 26 & 7 & & 44 & \\ \geq 2 / 3 & 23 & 34 & & 65 & \\ & & & & & \\ \begin{array}{l}\text { B-catenin } \\ \text { intensity }\end{array} & & & & & \\ \quad \text { None to weak } & 20 & 51 & 0.041 & 83 & 0.434 \\ \quad \text { Moderate } & 40 & 18 & & 46 & \\ \quad \text { Strong } & 24 & 20 & & 48 & \\ & & & & & \end{array}$

Table II. Continued.

\begin{tabular}{|c|c|c|c|c|c|}
\hline & $\mathrm{n}$ & $\begin{array}{l}\text { RFS } \\
\left(\mathrm{mo}^{\mathrm{a}}\right)\end{array}$ & p-value & $\begin{array}{c}\mathrm{OS} \\
\left(\mathrm{mo}^{\mathrm{a}}\right)\end{array}$ & $\mathrm{p}$-value \\
\hline \multicolumn{6}{|l|}{$\begin{array}{l}\text { B-catenin } \\
\text { extent }\end{array}$} \\
\hline$<1 / 3$ & 24 & 29 & 0.403 & 53 & 0.821 \\
\hline$\geq 1 / 3,<2 / 3$ & 31 & 14 & & 44 & \\
\hline$\geq 2 / 3$ & 29 & 33 & & 48 & \\
\hline \multicolumn{6}{|l|}{$\begin{array}{l}\text { Vascular } \\
\text { invasion }\end{array}$} \\
\hline Yes & 23 & 7 & 0.164 & 24 & 0.110 \\
\hline No & 61 & 27 & & 51 & \\
\hline \multicolumn{6}{|l|}{ Grade } \\
\hline Low (I-II) & 47 & 21 & 0.353 & 53 & 0.181 \\
\hline High (III-IV) & 37 & 26 & & 43 & \\
\hline
\end{tabular}

Univariate analysis indicated that RFS significantly correlated with UICC T stage and N-cadherin and B-catenin intensities ( $\mathrm{p}=0.031,0.014$ and 0.041 , respectively), whereas OS was significantly associated with UICC T stage $(\mathrm{p}=0.039)$ (Table II). Multivariate analysis employing parameters that showed $\mathrm{p}<0.100$ by univariate analysis revealed that both UICC $\mathrm{T}$ stage and $\mathrm{N}$-cadherin intensity independently predicted RFS ( $\mathrm{p}=0.025$ and 0.018 , respectively) as well as OS ( $p=0.013$ and 0.034 , respectively) (Table III). In the UICC T1 and T2/3 groups, median RFS times were 33 and 7 months, respectively (Fig. 6A), and median OS times were 53 and 24 months, respectively (Fig. 6B). In the none to weak, moderate, and strong $\mathrm{N}$-cadherin intensity groups, median RFS times were 41, 20, and 12 months, respectively (Fig. 7A), and median OS times were 104, 50, and 39 months, respectively (Fig. 7B). No significant association was found between $\mathrm{N}$-cadherin expression and UICC $\mathrm{T}$ staging in these patients $(\mathrm{p}=0.645)$. Therefore, these results collectively imply that advanced UICC $\mathrm{T}$ stage and tumoral $\mathrm{N}$-cadherin up-regulation are independent predictors of poor RFS and OS in HCC patients.

\section{Discussion}

The principal finding of this study relates to $\mathrm{N}$-cadherin signaling in HCC. Collectively, our results demonstrate that $\mathrm{N}$-cadherin-dependent signaling attenuates apoptosis in human $\mathrm{HCC}$ cells. In addition, tumoral $\mathrm{N}$-cadherin up-regulation was associated with poor RFS and OS in HCC patients following resection. These findings implicate $\mathrm{N}$-cadherin signaling in the progression of HCCs. Each of these findings will be discussed below.

The present study demonstrated $\mathrm{N}$-cadherin expression in cultured HCC cells as well as in resected human HCC tissue. $\mathrm{N}$-cadherin expression has been reported to cause tumor cells to become motile, invasive, and metastatic $(5,6)$. This invasive effect of $\mathrm{N}$-cadherin results, at least in part, from a functional 
Table III. Multivariate analysis of factors affecting RFS and OS.

\begin{tabular}{|c|c|c|c|c|}
\hline \multicolumn{2}{|c|}{ Variable } & \multirow[t]{2}{*}{$\begin{array}{l}\text { Odds } \\
\text { ratio }\end{array}$} & \multirow[t]{2}{*}{$95 \% \mathrm{CI}$} & \multirow{2}{*}{$\frac{p \text {-value }}{0.025}$} \\
\hline RFS & UICC T & & & \\
\hline & $\mathrm{T} 1$ & 1.000 & & \\
\hline & $\mathrm{T} 2 / 3$ & 1.930 & $1.087-3.426$ & \\
\hline & $\mathrm{N}$-cadherin intensity & & & 0.018 \\
\hline & None to weak & 1.000 & & \\
\hline & Moderate & 1.727 & $0.905-3.293$ & \\
\hline & Strong & 2.792 & $1.373-5.679$ & \\
\hline & ß-catenin intensity & & & NS \\
\hline OS & UICC T & & & 0.013 \\
\hline & $\mathrm{T} 1$ & 1.000 & & \\
\hline & $\mathrm{T} 2 / 3$ & 2.153 & $1.179-3.931$ & \\
\hline & $\mathrm{N}$-cadherin intensity & & & 0.034 \\
\hline & None to weak & 1.000 & & \\
\hline & Moderate & 1.507 & $0.773-2.940$ & \\
\hline & Strong & 2.606 & $1.264-5.375$ & \\
\hline
\end{tabular}

NS, not significant.

interaction with the FGF receptor at the cell membrane $(19,20)$. A complex between N-cadherin and FGFR-1 results in enhanced FGFR tyrosine phosphorylation, and sustained MAPK-ERK activation, leading to MMP-9 gene transcription and hence cellular invasion. N-cadherin is also likely to facilitate the systemic dissemination of tumor cells by enabling these cells to easily associate with stroma or endothelium at distant loci $(6,21)$.

In addition to promoting invasion and dissemination, $\mathrm{N}$-cadherin has been reported to exert an anti-apoptotic effect by recruiting phosphatidylinositol 3-kinase to the $\mathrm{N}$-cadherin/catenin/actin complex and thus increase the Bcl-2/ Bax protein ratio (11). However, in the present study, the expression levels of Bcl-2 and Bax were no different between $\mathrm{NCad} \Delta \mathrm{C}$ and control cells. Therefore, the present study describes an additional form of anti-apoptotic $\mathrm{N}$-cadherin related signaling in HCCs. In the present study, apoptosis was induced in HCC cells by treating with bile acid, which mediates its effect by activating death receptor-dependent pro-apoptotic signals. The Huh-BAT cells used in this study do not express Fas, and thus bile acid-induced apoptosis proceeds via the TRAIL-R2/DR5-dependent pathway (12). We observed that bile acid-induced caspase- 8 and its downstream signal activation were significantly up-regulated in $\mathrm{NCad} \Delta \mathrm{C}$ cells versus control cells. This up-regulated caspase- 8 activation is either due to enhanced procaspase- 8 cleavage or increased procaspase-8 recruitment to DISC. However, bile acid-induced TRAIL-R2/DR5, c-FLIP and caspase-10 modulation occurred in a similar way in $\mathrm{NCad} \Delta \mathrm{C}$ and control cells. Therefore, it is likely that procaspase- 8 is more efficiently recruited to DISC in $\mathrm{NCad} \Delta \mathrm{C}$ cells versus
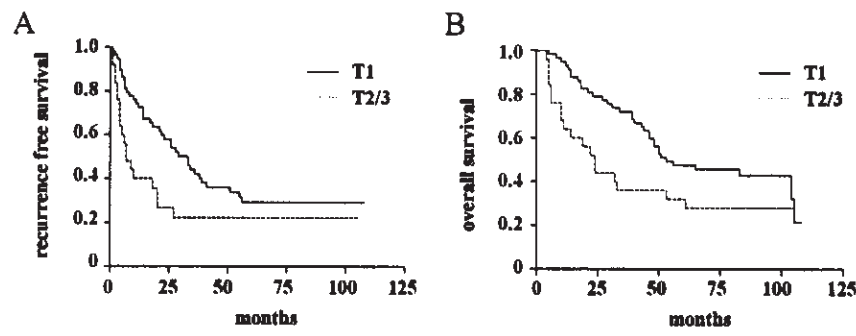

Figure 6. UICC T stage as an independent predictor of RFS and OS in HCC patients. (A) RFS curves according to UICC T stage are shown. Median RFS times were 33 and 7 months for $\mathrm{T} 1$ and T2/3 patients, respectively. (B) OS curves according to UICC T stage are shown. Median OS times were 53 and 24 months for $\mathrm{T} 1$ and $\mathrm{T} 2 / 3$ patients, respectively.
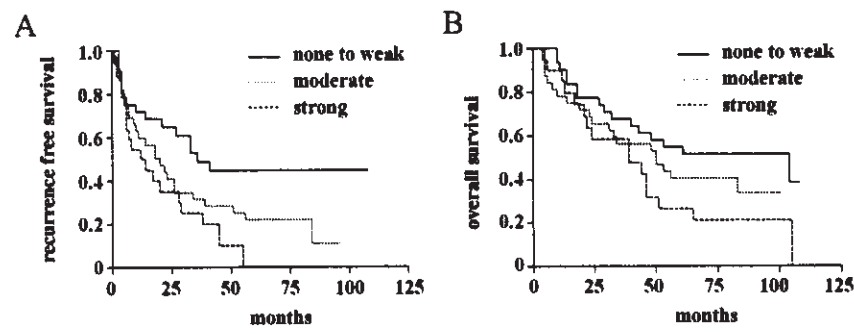

Figure 7. N-cadherin intensity as an independent predictor of RFS and OS in HCC patients. (A) RFS curves according to N-cadherin intensity are shown. Median RFS times were 41, 20, and 12 months in the none to weak, moderate, and strong $\mathrm{N}$-cadherin intensity groups, respectively. (B) OS curves with respect to $\mathrm{N}$-cadherin intensity are shown. Median OS times were 104,50 , and 39 months in the none to weak, moderate, and strong intensity groups, respectively.

control cells. Indeed, the present study demonstrates that $\mathrm{N}$-cadherin complexes with procaspase- 8 , and this association is diminished more so in $\mathrm{NCad} \Delta \mathrm{C}$ cells than in controls. Moreover, bile acid-induced procaspase- 8 recruitment to FADD was significantly enhanced in $\mathrm{NCad} \Delta \mathrm{C}$ cells. Therefore, these findings collectively imply that $\mathrm{N}$-cadherin signaling exerts an anti-apoptotic function in HCC cells by complexing with procaspase- 8 , and this is followed by reduced procaspase- 8 recruitment to DISC.

Based on this anti-apoptotic activity of N-cadherin, we evaluated whether tumoral $\mathrm{N}$-cadherin expression is associated with tumor recurrence or postoperative survival in HCC patients. In our evaluation of prognostic factors in these patients, we included the clinicopathological variables of age, sex, viral hepatitis, child classification, staging system, multiplicity, vascular invasion and grade, and the cadherin signaling parameters of E-cadherin, $\mathrm{B}$-catenin and $\mathrm{N}$-cadherin expression. Of these, tumoral $\mathrm{N}$-cadherin up-regulation and advanced UICC $\mathrm{T}$ stage were found to be independently related to poor RFS and OS by multivariate analysis. Therefore, our findings suggest that $\mathrm{N}$-cadherin up-regulation is an independent prognostic factor in HCC patients.

In conclusion, the current study demonstrates that $\mathrm{N}$-cadherin signaling exerts an anti-apoptotic effect in human HCCs, and thus probably participates in HCC progression. Therefore, we propose that $\mathrm{N}$-cadherin up-regulation in tumor tissue should be considered a prognostic marker of 
HCC, and the interruption of this signaling may have therapeutic potential.

\section{Acknowledgements}

This study was supported by grants from the Korea Health 21 R\&D Project (0412-CR01-0704-0001) and Korea Research Foundation (KRF-2004-041-E00140).

\section{References}

1. Korn WM: Moving toward an understanding of the metastatic process in hepatocellular carcinoma. World J Gastroenterol 7 : 777-778, 2001 .

2. Endo K, Ueda T, Ueyama J, Ohta $\mathrm{T}$ and Terada T: Immunoreactive E-cadherin, alpha-catenin, beta-catenin, and gamma-catenin proteins in hepatocellular carcinoma: relationships with tumor grade, clinicopathologic parameters, and patients' survival. Hum Pathol 31: 558-565, 2000.

3. Berx G, Cleton-Jansen AM, Nollet F, de Leeuw WJ, van de Vijver M, Cornelisse C and van Roy F: E-cadherin is a tumour/ invasion suppressor gene mutated in human lobular breast cancers. EMBO J 14: 6107-6115, 1995.

4. Behrens J, von Kries JP, Kuhl M, Bruhn L, Wedlich D, Grosschedl R and Birchmeier W: Functional interaction of B-catenin with the transcription factor LEF-1. Nature 382: 638-642, 1996.

5. Nieman MT, Prudoff RS, Johnson KR and Wheelock MJ: Ncadherin promotes motility in human breast cancer cells regardless of their E-cadherin expression. J Cell Biol 147: 631-644, 1999.

6. Hazan RB, Phillips GR, Qiao RF, Norton L and Aaronson SA: Exogenous expression of $\mathrm{N}$-cadherin in breast cancer cells induces cell migration, invasion, and metastasis. J Cell Biol 148: 779-790, 2000.

7. Redies $\mathrm{C}$ and Takeichi M: Expression of N-cadherin mRNA during development of the mouse brain. Dev Dyn 197: 26-39, 1993.

8. Hatta K, Takagi S, Fujisawa $\mathrm{H}$ and Takeichi M: Spatial and temporal expression pattern of $\mathrm{N}$-cadherin cell adhesion molecules correlated with morphogenetic processes of chicken embryos. Dev Biol 120: 215-227, 1987.
9. Hatta $\mathrm{K}$ and Takeichi M: Expression of N-cadherin adhesion molecules associated with early morphogenetic events in chick development. Nature 320: 447-449, 1986.

10. Bixby JL and Zhang R: Purified N-cadherin is a potent substrate for the rapid induction of neurite outgrowth. J Cell Biol 110: $1253-1260,1990$

11. Tran NL, Adams DG, Vaillancourt RR and Heimark RL: Signal transduction from N-cadherin increases Bcl-2. J Biol Chem 277 . 32905-32914, 2002

12. Higuchi H, Bronk SF, Takikawa Y, Werneburg N, Takimoto R, El-Deiry W and Gores GJ: The bile acid glycochenodeoxycholate induces trail-receptor 2/DR5 expression and apoptosis. J Biol Chem 276: 38610-38618, 2001.

13. Park JG, Lee JH, Kang MS, Park KJ, Jeon YM, Lee HJ, Kwon HS, Park HS, Yeo KS, Lee KU, Kim ST, Chung JK, Hwang YJ, Lee HS, Kim CY, Lee YI, Chen TR, Hay RJ, Song SY, Kim WH, Kim CW and Kim YI: Characterization of cell lines established from human hepatocellular carcinoma. Int J Cancer 62: 276-282, 1995.

14. Lee JH, Ku JL, Park YJ, Lee KU, Kim WH and Park JG: Establishment and characterization of four human hepatocellular carcinoma cell lines containing hepatitis B virus DNA. World J Gastroenterol 5: 289-295, 1999.

15. Kintner C: Regulation of embryonic cell adhesion by the cadherin cytoplasmic domain. Cell 69: 225-236, 1992.

16. Hermiston ML and Gordon JI: In vivo analysis of cadherin function in the mouse intestinal epithelium: Essential roles in adhesion, maintenance of differentiation, and regulation of programmed cell death. J Cell Biol 129: 489-506, 1995.

17. Fujimori $\mathrm{T}$ and Takeichi M: Disruption of epithelial cell-cell adhesion by exogenous expression of a mutated nonfunctional N-cadherin. Mol Biol Cell 4: 37-47, 1993.

18. Nieman MT, Kim JB, Johnson KR and Wheelock MJ: Mechanism of extracellular domain-deleted dominant negative cadherins. J Cell Sci 112: 1621-1632, 1999.

19. Suyama K, Shapiro I, Guttman M and Hazan RB: A signaling pathway leading to metastasis is controlled by $\mathrm{N}$-cadherin and the FGF receptor. Cancer Cell 2: 301-314, 2002.

20. Kim JB, Islam S, Kim YJ, Prudoff RS, Sass KM, Wheelock MJ and Johnson KR: N-Cadherin extracellular repeat 4 mediates epithelial to mesenchymal transition and increased motility. J Cell Biol 151: 1193-1206, 2000.

21. Hazan RB, Kang L, Whooley BP and Borgen PI: N-cadherin promotes adhesion between invasive breast cancer cells and the stroma. Cell Adhes Commun 4: 399-411, 1997. 